\title{
SOIL USES DURING THE SUGARCANE FALLOW PERIOD: INFLUENCE ON SOIL CHEMICAL AND PHYSICAL PROPERTIES AND ON SUGARCANE PRODUCTIVITY( ${ }^{(1)}$
}

\author{
Roniram Pereira da Silva ${ }^{(2)} \&$ Carolina Fernandes ${ }^{(3)}$
}

\begin{abstract}
SUMMARY
The planting of diversified crops during the sugarcane fallow period can improve the chemical and physical properties and increase the production potential of the soil for the next sugarcane cycle. The primary purpose of this study was to assess the influence of various soil uses during the sugarcane fallow period on soil chemical and physical properties and productivity after the first sugarcane harvest. The experiment was conducted in two areas located in Jaboticabal, São Paulo State, Brazil ( $\left(21^{\circ} 14^{\prime} 05^{\prime \prime} \mathrm{S}, 48^{\circ} 17^{\prime} 09^{\prime \prime} \mathrm{W}\right)$ with two different soil types, namely: an eutroferric Red Latosol (RLe) with high-clay texture (clay content $=680 \mathrm{~g} \mathrm{~kg}^{-1}$ ) and an acric Red Latosol (RLa) with clayey texture (clay content $=440 \mathrm{~g} \mathrm{~kg}^{-1}$ ). A randomized block design with five replications and four treatments (crop sequences) was used. The crop sequences during the sugarcane fallow period were soybean/millet/soybean, soybean/sunn hemp/soybean, soybean/fallow/ soybean, and soybean. Soil use was found not to affect chemical properties and sugarcane productivity of RLe or RLa. The soybean/millet/soybean sequence improved aggregation in the acric Latosol.
\end{abstract}

Index terms: crop diversification, soybean, millet, sunn hemp.

RESUMO: USOS DO SOLO NO PERÍODO DA REFORMA DO CANAVIAL: ATRIBUTOS QUÍMICOS E FÍSICOS DO SOLO E PRODUTIVIDADE $D A C A N A-D E-A C ̧ U ́ C A R$

A diversificação de culturas, no período de reforma do canavial, pode contribuir para a melhoria dos atributos quimicos e físicos do solo, incrementando seu potencial produtivo para o próximo ciclo da cana-de-açúcar. O objetivo deste trabalho foi avaliar a influência de diferentes

(1) Part of the first author's Master's thesis and of a FAPESP-funded project (Process 2011/06491-0). Received for publication on March 26, 2013 and approved on November 27, 2013.

(2) Agronomic Engineer, Master in Agronomy (Soil Science), Department of Soil Science, FCAV/UNESP. Via de acesso Prof. Paulo Donato Catellane, s/nº. CEP 14884-900 Jaboticabal (SP), Brazil. CAPES grant holder. E-mail: roniramsilva@hotmail.com

(3) Assistant Professor, Department of Soil Science, FCAV/UNESP, Jaboticabal Campus. E-mail: carol@fcav.unesp.br 


\begin{abstract}
usos do solo, no período de reforma do canavial, nos atributos químicos e físicos do solo e na produtividade da cana-de-açúcar, avaliados após o primeiro corte. Oexperimento foi conduzido

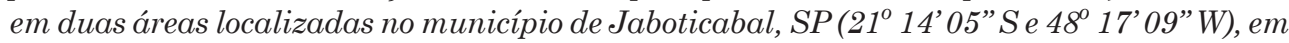
um Latossolo Vermelho eutroférrico (LVef) textura muito argilosa (argila $=680 \mathrm{~g} \mathrm{~kg}^{-1}$ ) e um Latossolo Vermelho ácrico $(\mathrm{LVw})$ textura argilosa (argila $=440 \mathrm{~g} \mathrm{~kg}^{-1}$ ). $O$ delineamento experimental foi em blocos casualizados com cinco repetições e quatro tratamentos, caracterizados por diferentes usos do solo no periodo de reforma do canavial (soja / milheto / soja, soja/crotalária/soja, soja/pousio/soja e soja). Os diferentes usos do solo não influenciaram os atributos químicos do solo e a produtividade da cana-de-açúcar no LVefe no $L V w$. O uso soja / milheto /soja favoreceu a agregação do LVw.
\end{abstract}

Termos de indexação: diversificação de culturas, soja, milheto, crotalária.

\section{INTRODUCTION}

Sugarcane was introduced in Brazil during the colonial period and gradually became one of the main crops in the national economy. In fact, Brazil is the world's greatest producer of sugarcane, as well as of sugar and ethanol (Brasil, 2012). In the 2012/13 growing season, the area of cane cultivation for sugar and energy production covered an estimated 8.52 million ha and the predicted sugarcane production for milling was 595.13 million tons - a $6.2 \%$ increase from the previous season (CONAB, 2012).

The present scenario demonstrates the global interest in bioenergy and the bright expansion prospects for the sugar and energy industry despite the opposition of those who consider sugarcane a monoculture. Thus, the sector is currently confronted with the challenge of demonstrating that competitive, sustainable increases in sugarcane production by technological means entail crop diversification, professionalization and integration of production chains, taking economic, social and environmental matters into consideration.

The benefits of crop diversification are wellknown, bearing in mind that the degradation of different crop residues alters soil properties and can influence the performance of subsequent crops (Marcelo et al., 2009). This has fostered the adoption of crop diversification (particularly in conservation systems) for the physical, chemical and biological management of soil. According to Ambrosano et al. (2005), crop rotation tends to increase macro and micronutrient availability in subsequent crops. They stated that legumes are commonly used due to their $\mathrm{N}$-fixation capacity and for containing phosphorus, potassium and calcium; in addition, the typically low $\mathrm{C} / \mathrm{N}$ ratio of legumes makes their nutrients more readily available than those of grasses. According to Andrade et al. (2009), the adoption of crop rotation to maintain or increase the contents of soil organic matter creating biological pores, improving the soil structure and retaining straw on the soil surface should be encouraged. Wohlenberg et al. (2004) found that crop sequences of grasses and legumes increased soil aggregation more than sequences of crucifers, composite and fallow. However, crop diversification should provide practical advantages and benefits for subsequent crops with a view to increasing profits while ensuring environmental sustainability.

Sugarcane is a semi-perennial crop, i.e., it is not planted every year and can be maintained for 4-8 years, depending on the particular pedoclimatic conditions. Therefore, crop diversification for sugarcane is limited to the fallow period, which usually spans the six months following harvesting of one crop prior to the planting of the next productive cycle. This period can be used to grow species that help improve the soil quality. One possibility for crop diversification with sugarcane is to use grain crops during the fallow period in order to boost annual profits.

Soybean is commonly used during the sugarcane fallow period. In fact, up to two soybean crops can be used in order to maximize their action on soil quality, break the pest and disease cycle, and increase grain production without reducing sugarcane productivity and longevity. In a study on a dystrophic Red Latosol in Sales de Oliveira, São Paulo, Mascarenhas et al. (1994) found the productivity of a sugarcane/legume sequence to be increased by about $26 \%$ by growing two soybean crops compared to no cultivation during the sugarcane fallow period. Their economic analysis revealed that overall benefits peaked with the additional profits from soybean sales.

Based on the foregoing, there is a clear need to define maximized land use during the sugarcane fallow period with a view to diversifying crops without disregarding economic and environmental concerns. The working hypothesis of this study was that using two soybean crops with one interim legume crop in the sugarcane fallow period improves chemical and physical properties and raises the production potential of the soil for the following sugarcane cycle. Therefore, the primary purpose was to assess the influence of soil use during the sugarcane fallow period on these properties after the first harvest, and on productivity in the first 
and second harvest of the following sugarcane cycle cultured in a eutroferric Red Latosol and an acric Red Latosol.

\section{MATERIAL AND METHODS}

This work was part of a long-term study of a sugarcane fallow (October 2008-February 2010) and of the overall sugarcane cycle that was initiated in February 2010 and will continue until the next cane fallow period.

The experiment was performed in two areas in the municipality of Jaboticabal, São Paulo State $\left(21^{\circ} 14^{\prime} 05^{\prime \prime} \mathrm{S}, 48^{\circ} 17^{\prime} 09^{\prime \prime} \mathrm{W}\right.$, average height above sea level of $615.01 \mathrm{~m})$. The soil in one area was a eutroferric Red Latosol $\left(\mathrm{RL}_{\mathrm{e}}\right)$ with high-clay texture ( sand $=140 \mathrm{~g} \mathrm{~kg}^{-1}$, silt $=180 \mathrm{~g} \mathrm{~kg}^{-1}$ and clay $=680 \mathrm{~g} \mathrm{~kg}^{-1}$ in the $0.00-0.20 \mathrm{~m}$ layer $)$ and that in the other an acric Red Latosol $\left(\mathrm{RL}_{\mathrm{a}}\right)$ with clayey texture (sand $=440 \mathrm{~g} \mathrm{~kg}^{-1}$, silt $=120 \mathrm{~g} \mathrm{~kg}^{-1}$ and clay $=440 \mathrm{~g} \mathrm{~kg}^{-1}$ in the 0.00-0.20 m layer). The prevailing climate at the study site is Aw according to Köppen's classification and the average temperature of the warmest and coldest month are 22 and $18{ }^{\circ} \mathrm{C}$, respectively. The mean annual pluvial precipitation from 1971 to 2000 was $1,424.60 \mathrm{~mm}$, with an annual rainy season lasting from October to March and a dry season from April to September. In both studied areas sugarcane was harvested green for more than 30 years and mechanically harvested since 1995 previously, crops were harvested by hand and the trash burnt on site.

The experiment was arranged in a randomized block design, with four treatments (crops in the sugarcane fallow period) and five replications. The crops used in the fallow period (October 2008 to February 2010) were as follows: soybean/millet/ soybean (SMS), soybean/sunn hemp/soybean (SHS), soybean/fallow/soybean (SFS) and soybean (S). In these treatments SMS, SHS and SFS, two soybean (Glycine $\max$ L.) crops were grown (from October 2008 to February 2009 and October 2009 to February 2010). The period in-between (from March to September 2009), was used to plant millet (Pennisetum americanum) in SMS and sunn hemp (Crotalaria juncea) in SHS or for a fallow period (SFS), with periodic hoeing in order to remove spontaneous vegetation and clear the soil. The $\mathrm{S}$ treatment (October 2009 to February 2010) involved a soybean crop. The one-year lag between $\mathrm{S}$ and the other treatments (SMS, SHS and SFS) was conditioned by the need to obtain the first sugarcane harvest as well as the subsequent harvests in the same growing season for the four soil uses, to enable statistical comparisons of the results.

Prior to the experiment, sugarcane stubble from the previous cycle was removed by mechanical means.
The soybean variety Coodetec 216 was sown in the different treatments in two growing seasons (2008/ 2009 and 2009/2010). Rows were spaced $0.45 \mathrm{~m}$ apart to obtain a density of 400000 plants ha $^{-1}$ and a 03-3010 N-P-K fertilizer mixture was applied at sowing $\left(0.30 \mathrm{Mg} \mathrm{ha}^{-1}\right)$. Pest and diseases during the soybean cycle were controlled as per the crop-specific phytotechnical recommendations. Soybean was harvested with a mechanical plot harvester about 120 days after sowing.

Millet and sunn hemp were sown with a no-tillage drill, in rows spaced $0.45 \mathrm{~m}$ apart without fertilization at planting, for a crop density of 3000000 plants ha $^{-1}$ for millet and 555500 plants ha-1 for sunn hemp. The crops were harvested by a mechanical plot harvester 144 (millet) and 166 days after sowing (sunn hemp).

The plots left fallow were periodically hoed to clear the soil of spontaneous vegetation in order to facilitate comparison with the treatments including millet or sunn hemp between the two soybean crops.

More detailed information about the installation, management and harvesting of the crops used during the fallow period can be found elsewhere (Fernandes et al., 2012).

The different crops used during the fallow period were followed by mechanical planting of sugarcane in February 2010, using the variety SP 87-365 on $\mathrm{RL}_{\mathrm{e}}$ and $\mathrm{RB}$ 83-5054 on $\mathrm{RL}_{\mathrm{a}}$. The crops were managed according to specific phytotechnical recommendations and the soil fertilized according to Spironello et al. (1997).

Each experimental plot $\left(18 \times 15 \mathrm{~m}\right.$ or $\left.270 \mathrm{~m}^{2}\right)$ consisted of twelve 15-m long sugarcane rows spaced $1.5 \mathrm{~m}$ apart of which an area of $120 \mathrm{~m}^{2}$ (i.e., eight 10 $\mathrm{m}$ long sugarcane rows) was evaluated. The plot borders consisted of the two outer rows on each side and $2.5 \mathrm{~m}$ on either end of the rows. Within each block, the plots were separated by 10 -m corridors and the blocks by $3-\mathrm{m}$ corridors. The plot and corridor sizes were defined so as to facilitate agricultural machinery operations of crop management.

Disturbed soil samples were collected for determining chemical properties and the water stability of soil aggregates (WSA) after the first sugarcane harvest in June 2011 (i.e., 16 months after planting the crop). One soil sample per layer and plot was collected with a Dutch auger (layers 0.00-0.10, $0.10-0.20,0.20-0.40$ and $0.40-0.60 \mathrm{~m})$. The specific soil properties studied were $\mathrm{pH}\left(\mathrm{CaCl}_{2}\right)$; the contents of organic matter $(\mathrm{OM})$; available $\mathrm{P}$; exchangeable $\mathrm{K}$, $\mathrm{Ca}$ and $\mathrm{Mg}$, and the potential acidity $(\mathrm{H}+\mathrm{Al})$; all were determined according to Raij et al. (2001). The resulting data were used to calculate the cationexchange capacity (CEC) and base saturation (BS) of the soils. The water stability was determined in soil aggregates with a diameter of 1.00-2.00 mm, using the method of Nimmo \& Perkins (2002). 
The aggregate mean weight diameter (AMWD) was calculated from samples with an appropriate moisture content for sampling from the 0.00-0.10 and 0.10-0.20 $\mathrm{m}$ layers collected in August 2011 (i.e., 18 months after planting). A mattock was used to collect three subsamples that were mixed to obtain a composite sample. The AMWD was determined in aggregates (diameter 4.00-6.30 mm), using sieves of 4.00, 2.00, $1.00,0.50,0.25$ and $0.125 \mathrm{~mm}$ mesh size, according to Nimmo \& Perkins (2002).

Undisturbed soil samples were also collected from the $0.00-0.10,0.10-0.20,0.20-0.40$ and $0.40-0.60 \mathrm{~m}$ layers, using volumetric rings $(0.05 \times 0.05 \mathrm{~m})$. Three samples were obtained per layer and plot in October 2011 (i.e., 20 months after sugarcane planting), when soil moisture was optimal for sampling. These samples were used to determine soil density $\left(\mathrm{D}_{\mathrm{s}}\right)$, according to Grossman \& Reinsch (2002); and total porosity $\left(\mathrm{P}_{\mathrm{T}}\right)$, macroporosity (Mac) and microporosity (Mic), according to Embrapa (1997). Three additional samples per plot were obtained from the 0.00-0.10 and $0.10-0.20 \mathrm{~m}$ soil layers in order to assess penetration resistance (PR), according to Tormena et al. (1998) and Lowery \& Morrison (2002). After pressurizing the samples at $100 \mathrm{hPa}$, equivalent to field capacity, PR was determined, as described by Reichardt (1988).

The first and second sugarcane crops in the two areas were harvested in June 2011 and June 2012, respectively. Productivity was assessed in the four central rows of the useful area per plot. To this end, the stalks were harvested by hand and those from the four $10-\mathrm{m}$ rows $\left(60 \mathrm{~m}^{2}\right)$ were weighed. The other plot rows were harvested mechanically, without stubble burning in either case. The yield was expressed in $\mathrm{Mg} \mathrm{ha}^{-1}$.

The results were subjected to analysis of variance at $\mathrm{p}=0.01$, followed by distribution into randomized blocks with five replications and four treatments (soil uses during the fallow period). Combined analyses of both soils were performed and their means compared by Tukey's test at $\mathrm{p}=0.05$.

\section{RESULTS AND DISCUSSION}

No influence of soil use on the chemical properties of the eutroferric Red Latosol $\left(\mathrm{RL}_{\mathrm{e}}\right)$ or acric Red Latosol $\left(\mathrm{RL}_{\mathrm{a}}\right)$ was detected in any of the four soil layers studied (Tables 1 and 2). The similarity between values can be ascribed to the time measurements were made (16 months after sugarcane planting). Possibly, the crop absorbed accumulated nutrients from the residue decomposition of the crops planted in the sugarcane fallow period.

In $\mathrm{RL}_{\mathrm{e}}$, WSA ranged from 70 to $80 \%$ and was unaffected by soil use (Table 3); in $\mathrm{RL}_{\mathrm{a}}$, WSA was significantly affected by soil use in the 0.10-0.20 m layer (Table 4). The difference in this variable between the two soils was probably a result of the higher clay content in $\mathrm{RL}_{\mathrm{e}}$ than $\mathrm{RL}_{\mathrm{a}}\left(680\right.$ vs $\left.440 \mathrm{~g} \mathrm{~kg}^{-1}\right)$, which must have led to a higher aggregate stability of the former.

In $\mathrm{RL}_{\mathrm{a}}$, the soil uses involving the inclusion of two soybean crops required more agricultural operations, resulting in lower WSA values (Table 4). On the other hand, the sequence including millet (SMS) led to WSA values similar to that of soybean (S) alone (59.20 vs 64.20, not significantly different by Tukey's test at $\mathrm{p}=0.05)$. Therefore, the soybean/ millet/soybean crop sequence (SMS) also increased WSA by effect of the greater number of agricultural operations involved. This result confirms the favourable effect of grass-legume rotations on soil aggregation.

Wohlenberg et al. (2004) found a direct influence of crops on aggregate formation and stabilization, and greater aggregate stability under crops supplying organic matter and covering the soil throughout the year. According to them, different crop sequences have differential effects on soil aggregation, depending on the season and time of crop establishment; also, crop rotations involving grass and legumes increase soil aggregation. This is the result of the slower degradation of degradation-resistant materials such as lignin and phenolic compounds, which form humic substances in soil by associations with microbial synthesized products. Therefore, the large amounts of undegraded substances (viz., lignin and, especially, phenolic compounds) present in plant residues must be responsible for the effect of plants on aggregate stability in soil; according to Martens (2000), plants generally contain the same biochemical classes of organic products, e.g., carbohydrates, amides, proteins, lipids and phenols, albeit in variable proportions, depending on the particular species, which influences the extent and rate of degradation. Thus, organic materials with a low $\mathrm{C} / \mathrm{N}$ ratio (as in legumes) can help preserve soil fertility with crop sequences including both grasses and legumes. This is an effective strategy for improving soil quality and minimizing physical degradation of Red Latosols in tropical regions with dry winters (Martins et al., 2012a,b; 2013).

Silva \& Mielniczuk (1997) noted the especially beneficial effects of grasses on aggregate formation and stability - a result of the characteristics of their root system, mainly. In fact soil particles are drawn closer to each other by the high root density of grasses; also, periodic renewals of the root system and the uniform distribution of soil exudates stimulate the microbial activity and hence the formation of by-products involved in aggregate formation and stabilization. Therefore, grass roots may be responsible for the mechanism and substances that join small particles in larger aggregates. 
Table 1. Chemical properties of the eutroferric Red Latosol after the first sugarcane harvest

\begin{tabular}{|c|c|c|c|c|c|c|c|c|c|}
\hline Soil use & $\mathrm{pH}\left(\mathrm{CaCl}_{2}\right)$ & $\mathrm{OM}$ & $\mathrm{P}$ resin & $\mathbf{K}$ & $\mathrm{Ca}$ & $\mathrm{Mg}$ & $\mathrm{H}+\mathrm{Al}$ & CEC & BS \\
\hline & & $\mathrm{g} \mathrm{kg}^{-1}$ & $\mathrm{mg} \mathrm{dm} \mathrm{m}^{-3}$ & $\longrightarrow$ & 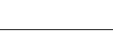 & $\mathrm{nmol}_{\mathrm{c}} \mathrm{dm}$ & & & $\%$ \\
\hline \multicolumn{10}{|c|}{$0.00-0.10 \mathrm{~m}$} \\
\hline $\mathrm{S}$ & 5.26 & 28.77 & 30.60 & 1.72 & 42.40 & 16.60 & 40.60 & 101.32 & 59.32 \\
\hline SFS & 5.22 & 29.18 & 49.80 & 1.42 & 44.40 & 15.60 & 40.00 & 101.42 & 60.26 \\
\hline SMS & 5.36 & 29.38 & 60.80 & 1.90 & 50.00 & 19.60 & 37.00 & 108.50 & 65.94 \\
\hline SHS & 5.42 & 30.81 & 56.60 & 1.84 & 50.60 & 18.40 & 37.20 & 108.04 & 65.53 \\
\hline $\mathrm{F}$ & $0.64^{\mathrm{ns}}$ & $1.86^{\mathrm{ns}}$ & $1.69^{\mathrm{ns}}$ & $0.47^{\mathrm{ns}}$ & $1.53^{\mathrm{ns}}$ & $1.23^{\text {ns }}$ & $0.31^{\mathrm{ns}}$ & $3.39^{\text {ns }}$ & $0.73^{\mathrm{ns}}$ \\
\hline CV (\%) & 4.80 & 4.92 & 46.52 & 40.28 & 15.71 & 20.61 & 19.23 & 4.62 & 14.38 \\
\hline \multicolumn{10}{|c|}{$0.10-0.20 \mathrm{~m}$} \\
\hline $\mathrm{S}$ & 5.02 & 25.10 & 25.60 & 1.52 & 30.80 & 13.00 & 39.00 & 84.32 & 53.48 \\
\hline SFS & 4.96 & 25.10 & 29.00 & 1.16 & 29.40 & 12.40 & 40.60 & 83.56 & 51.13 \\
\hline SMS & 5.18 & 26.32 & 54.80 & 1.60 & 34.40 & 15.40 & 36.00 & 87.40 & 58.36 \\
\hline SHS & 5.08 & 25.91 & 37.80 & 1.56 & 33.40 & 13.80 & 39.60 & 88.36 & 54.96 \\
\hline $\mathrm{F}$ & $0.58^{\mathrm{ns}}$ & $0.54^{\mathrm{ns}}$ & $0.80^{\mathrm{ns}}$ & $0.66^{\mathrm{ns}}$ & $0.53^{\text {ns }}$ & $0.50^{\mathrm{ns}}$ & $0.53^{\mathrm{ns}}$ & $0.88^{\mathrm{ns}}$ & $0.52^{\mathrm{ns}}$ \\
\hline CV (\%) & 5.43 & 7.28 & 88.46 & 38.25 & 22.18 & 30.12 & 15.70 & 6.46 & 17.15 \\
\hline \multicolumn{10}{|c|}{$0.20-0.40 \mathrm{~m}$} \\
\hline $\mathrm{S}$ & 4.88 & 21.22 & 18.40 & 1.34 & 23.00 & 11.40 & 44.80 & 80.54 & 44.68 \\
\hline SFS & 4.78 & 20.81 & 15.80 & 1.04 & 21.00 & 10.20 & 46.00 & 78.24 & 41.14 \\
\hline SMS & 4.98 & 19.59 & 20.00 & 1.24 & 24.20 & 12.80 & 40.60 & 78.84 & 48.91 \\
\hline SHS & 4.96 & 20.61 & 16.00 & 1.46 & 26.40 & 12.40 & 42.20 & 82.46 & 48.40 \\
\hline $\mathrm{F}$ & $0.74^{\mathrm{ns}}$ & $0.56^{\mathrm{ns}}$ & $0.35^{\mathrm{ns}}$ & $0.91^{\mathrm{ns}}$ & $0.73^{\mathrm{ns}}$ & $0.90^{\mathrm{ns}}$ & $0.51^{\mathrm{ns}}$ & $0.61^{\mathrm{ns}}$ & $0.78^{\text {ns }}$ \\
\hline CV (\%) & 4.82 & 10.05 & 43.59 & 32.75 & 24.97 & 23.38 & 17.62 & 6.79 & 20.02 \\
\hline \multicolumn{10}{|c|}{$0.40-0.60 \mathrm{~m}$} \\
\hline $\mathrm{S}$ & 4.84 & 13.67 & 5.60 & 1.18 & 15.60 & 8.20 & 31.00 & 55.98 & 44.26 \\
\hline SFS & 4.80 & 14.28 & 6.40 & 1.08 & 14.60 & 7.60 & 31.00 & 54.28 & 42.85 \\
\hline SMS & 5.04 & 15.71 & 10.40 & 1.66 & 19.20 & 10.20 & 27.60 & 58.66 & 53.19 \\
\hline SHS & 4.94 & 13.87 & 6.60 & 1.18 & 19.00 & 9.20 & 29.20 & 58.58 & 49.76 \\
\hline $\mathrm{F}$ & $1.88^{\mathrm{ns}}$ & $1.58^{\mathrm{ns}}$ & $1.08^{\mathrm{ns}}$ & $1.04^{\mathrm{ns}}$ & $3.50^{\mathrm{ns}}$ & $1.69^{\mathrm{ns}}$ & $1.29^{\mathrm{ns}}$ & $1.03^{\text {ns }}$ & $3.20^{\mathrm{ns}}$ \\
\hline CV (\%) & 3.57 & 11.36 & 63.74 & 44.91 & 16.40 & 22.34 & 10.85 & 8.26 & 12.66 \\
\hline
\end{tabular}

S: soybean, SFS: soybean/fallow/soybean, SMS: soybean/millet/soybean, SHS: soybean/sunn hemp/soybean. ${ }^{\text {ns }}$ not significant.

The WSA values of $\mathrm{RL}_{\mathrm{e}}$ were statistically greater than those of $\mathrm{RL}_{\mathrm{a}}$ at all depths sampled (Table 5). This was possibly the result of the higher content of OM (Table 5) and clay in $\mathrm{RL}_{\mathrm{e}}$ than $\mathrm{RL}_{\mathrm{a}}(680$ vs $\left.440 \mathrm{~g} \mathrm{~kg}^{-1}\right)$. Luca et al. (2008) determined physical properties and $\mathrm{C}$ and $\mathrm{N}$ contents in soils under sugarcane with and without burning at harvest and found increased $\mathrm{C}$ contents where clay contents were high, due to faster material degradation and humification in soils with high sand and low clay content. Souza et al. (2009) analysed the spatial variability of aggregate stability of Latosols under sugarcane and concluded that aggregate stability in a eutroferric Red Latosol containing $630 \mathrm{~g} \mathrm{~kg}^{-1}$ clay and $25.04 \mathrm{~g} \mathrm{~kg}^{-1} \mathrm{OM}$ in the $0.00-0.40 \mathrm{~m}$ layer exceeded that of a dystrophic Red Latosol containing $361 \mathrm{~g} \mathrm{~kg}^{-1}$ clay and $15.05 \mathrm{~g} \mathrm{~kg}^{-1} \mathrm{OM}$ in the same layer, by effect of the higher clay and OM contents of the former.
The aggregate mean weight diameter (AMWD) was influenced by soil use in the 0.10-0.20 m layer of $\mathrm{RL}_{\mathrm{e}}$ and the 0.00-0.10 m layer of $\mathrm{RL}_{\mathrm{a}}$ (Tables 3 and 4). The cultivation of a single soybean crop $(\mathrm{S})$ on $\mathrm{RL}_{\mathrm{e}}$ led to higher AMWD values than of two soybean crops, irrespective of the intervening crop: fallow (SFS), millet (SMS) or sunn hemp (SHS). Possibly, the increased number of agricultural operations involved reduced AMWD, consistent with results of Fernandes et al. (2012) obtained after the fallow period but before sugarcane planting (February 2010).

The cultivation of millet (SMS) on $\mathrm{RL}_{\mathrm{a}}$ led to AMWD values in the 0.00-0.10 m layer similar to those obtained with a single soybean crop (S), which confirms the above-mentioned favourable effect of a grasslegume rotation.

Soil uses had not a significant effect on penetration resistance in $\mathrm{RL}_{\mathrm{e}}$ and $\mathrm{RL}_{\mathrm{a}}$ (Tables 3 and 4). Both soils 
Table 2. Chemical properties of the acric Red Latosol after the first sugarcane harvest

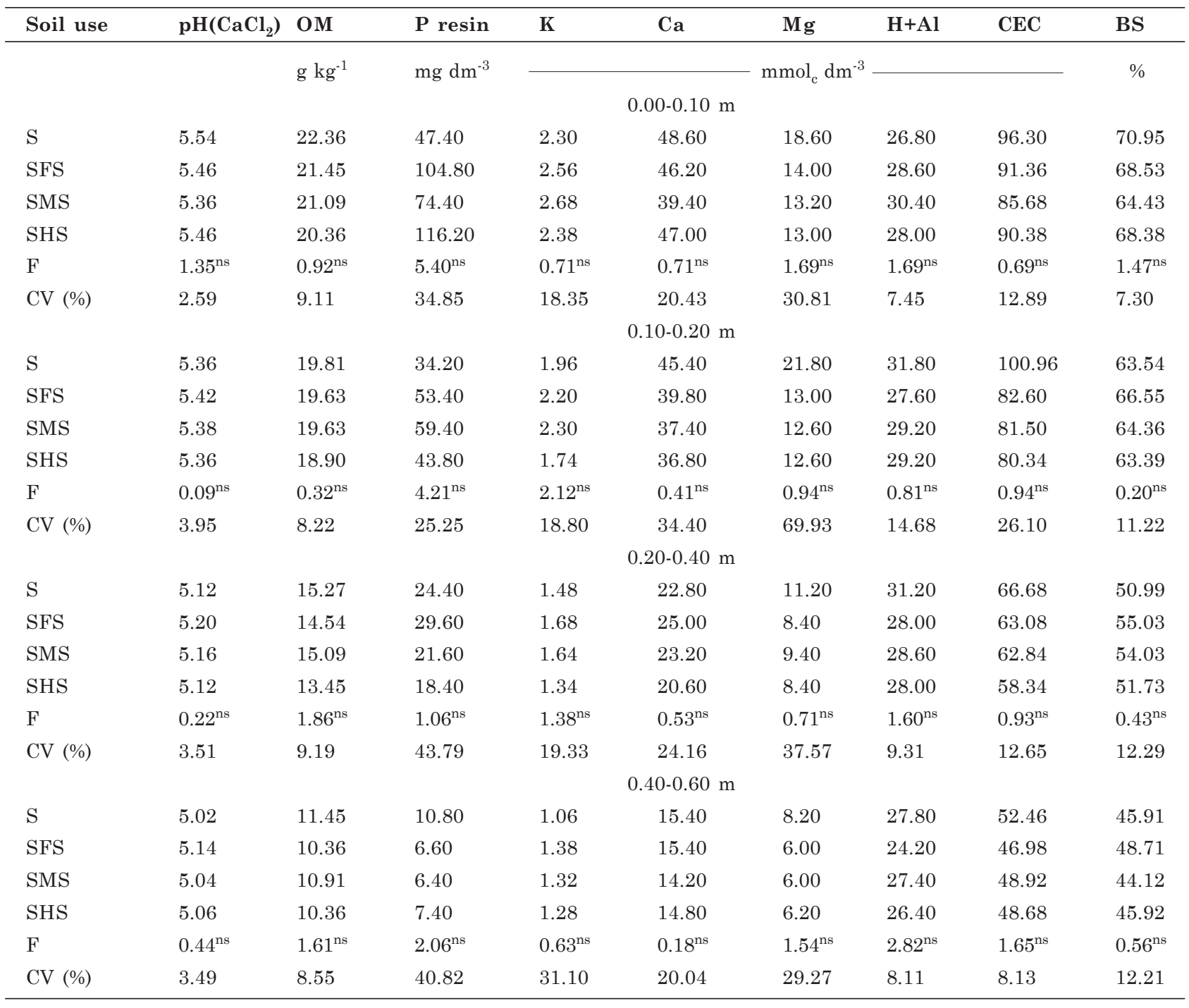

S: soybean, SFS: soybean/fallow/soybean, SMS: soybean/millet/soybean, SHS: soybean/sunn hemp/soybean. ${ }^{\text {ns }}$ not significant.

had PR $>2 \mathrm{MPa}$, which is the critical threshold for plant growth in general (Taylor et al., 1966).

Growth thresholds for plants differ between soil types and crops and critical limits are therefore difficult to set (Portugal et al., 2010). The reduced tillage in management practices of soil conservation, along with an increased land use, exposes the soil to heavy machinery traffic and alters its structural quality, thus leading to increased compaction in many conservatively managed areas (Carvalho et al., 2008). In any case, a root development threshold of $2 \mathrm{MPa}$ appears to be inappropriate for areas under conservation cultivation (Serafim et al., 2008). This value may in fact be too restrictive in the case of a fully compacted layer as found in pot experiments. However, one must consider that the natural heterogeneity of soils facilitates the formation of fissures and spaces for roots to grow and colonize soil
(Azevedo, 2008). As a result, soil compaction is especially detrimental to plant growth in dry soils (Assis et al., 2009). In fact, in soils with higher moisture roots can develop at penetration resistance levels above $4 \mathrm{MPa}$ (Dexter, 1987).

The soil uses influenced bulk density $\left(\mathrm{B}_{\mathrm{d}}\right)$ in $\mathrm{RL}_{\mathrm{e}}$, but only in the 0.00-0.10 m layer (Table 3 ), where the SMS treatment led to a lower $B_{d}$ value than $S$ (i.e., the soybean/millet/soybean sequence reduced soil density). On the other hand, no soil use had a significant effect on $B_{d}$ in $R_{2}$ (Table 4), although the density values were statistically higher than those in $\mathrm{RL}_{\mathrm{e}}$ (Table 5) in all layers. This result confirms previous findings of Luca et al. (2008), that $B_{d}$ increases with increasing sand content of the soil. According to them, soils with a low clay and high sand content are more prone to compaction for containing more macropores, which are less resistant to compaction. 
Table 3. Water stability of soil aggregates (WAS), aggregate mean weight diameter (AMWD), penetration resistance (PR), bulk density $\left(\mathrm{B}_{\mathrm{d}}\right)$, macroporosity (Mac), microporosity (Mic) and total porosity (TP) of the eutroferric Red Latosol after the first sugarcane harvest

\begin{tabular}{|c|c|c|c|c|c|c|c|}
\hline Soil use & WAS & AMWD & PR & $\mathbf{B}_{\mathrm{d}}$ & Mac & Mic & $\mathbf{T P}$ \\
\hline & $\%$ & $\mathrm{~mm}$ & $\mathrm{MPa}$ & $\mathrm{Mg} \mathrm{m}^{-3}$ & 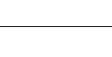 & $\mathrm{m}^{3} \mathrm{~m}^{-3}$ & \\
\hline & & & & $0.00-0.10 \mathrm{~m}$ & & & \\
\hline $\mathrm{S}$ & 76.80 & 2.68 & 3.58 & $1.50 \mathrm{a}$ & 0.03 & 0.46 & $0.49 \mathrm{~b}$ \\
\hline SFS & 74.20 & 2.50 & 3.35 & $1.46 \mathrm{ab}$ & 0.03 & 0.47 & $0.50 \mathrm{~b}$ \\
\hline SMS & 76.00 & 2.45 & 3.04 & $1.42 \mathrm{~b}$ & 0.04 & 0.48 & $0.52 \mathrm{a}$ \\
\hline SHS & 71.60 & 2.49 & 3.52 & $1.45 \mathrm{ab}$ & 0.04 & 0.47 & $0.51 \mathrm{ab}$ \\
\hline $\mathrm{F}$ & $1.62^{\mathrm{ns}}$ & $0.68^{\mathrm{ns}}$ & $0.58^{\mathrm{ns}}$ & $6.88^{* *}$ & $1.55^{\mathrm{ns}}$ & $3.94^{\mathrm{ns}}$ & $8.28^{* *}$ \\
\hline \multirow[t]{2}{*}{ CV (\%) } & 5.42 & 11.26 & 21.05 & 1.98 & 32.99 & 1.64 & 1.75 \\
\hline & 0.1 & & & $0-0.20 \mathrm{~m}$ & & & \\
\hline $\mathrm{S}$ & 75.80 & $2.78 \mathrm{a}$ & 3.54 & 1.49 & 0.07 & $0.43 \mathrm{~b}$ & 0.50 \\
\hline SFS & 74.60 & $2.21 \mathrm{~b}$ & 3.24 & 1.47 & 0.06 & $0.45 \mathrm{a}$ & 0.51 \\
\hline SMS & 78.00 & $2.15 \mathrm{~b}$ & 2.99 & 1.47 & 0.06 & $0.45 \mathrm{a}$ & 0.51 \\
\hline SHS & 74.00 & $2.18 \mathrm{~b}$ & 3.25 & 1.46 & 0.06 & $0.44 \mathrm{ab}$ & 0.50 \\
\hline $\mathrm{F}$ & $1.42^{\mathrm{ns}}$ & $17.12^{* *}$ & $0.66^{\text {ns }}$ & $0.71^{\mathrm{ns}}$ & $1.79^{\text {ns }}$ & $7.15^{* *}$ & $0.02^{\mathrm{ns}}$ \\
\hline \multirow[t]{2}{*}{ CV (\%) } & 4.38 & 7.01 & 18.95 & 2.21 & 18.70 & 1.16 & 2.17 \\
\hline & & & & $0.20-0.40 \mathrm{~m}$ & & & \\
\hline $\mathrm{S}$ & 78.00 & & & 1.49 & 0.07 & 0.43 & 0.50 \\
\hline SFS & 79.00 & & & 1.47 & 0.07 & 0.43 & 0.50 \\
\hline SMS & 79.40 & & & 1.49 & 0.07 & 0.44 & 0.51 \\
\hline SHS & 77.80 & & & 1.48 & 0.07 & 0.44 & 0.51 \\
\hline $\mathrm{F}$ & $0.22^{\mathrm{ns}}$ & & & $0.28^{\mathrm{ns}}$ & $0.22^{\mathrm{ns}}$ & $0.63^{\text {ns }}$ & $0.21^{\mathrm{ns}}$ \\
\hline \multirow[t]{2}{*}{ CV (\%) } & 4.70 & & & 2.76 & 26.52 & 2.55 & 2.56 \\
\hline & & & & $0.40-0.60 \mathrm{~m}$ & & & \\
\hline $\mathrm{S}$ & 78.20 & & & 1.45 & 0.08 & 0.44 & 0.52 \\
\hline SFS & 77.80 & & & 1.43 & 0.08 & 0.44 & 0.52 \\
\hline SMS & 80.00 & & & 1.43 & 0.09 & 0.44 & 0.53 \\
\hline SHS & 76.80 & & & 1.43 & 0.09 & 0.44 & 0.53 \\
\hline $\mathrm{F}$ & $2.02^{\mathrm{ns}}$ & & & $0.35^{\mathrm{ns}}$ & $0.76^{\text {ns }}$ & $1.38^{\mathrm{ns}}$ & $2.02^{\mathrm{ns}}$ \\
\hline CV (\%) & 2.69 & & & 3.35 & 25.50 & 1.91 & 2.72 \\
\hline
\end{tabular}

S: soybean, SFS: soybean/fallow/soybean, SMS: soybean/millet/soybean, SHS: soybean/sunn hemp/soybean. ${ }^{\mathrm{ns}}$ not significant, ** significant at the $\mathrm{p}=0.01$ level. Values followed by an identical letter in the same column were not significantly different by Tukey's test at $\mathrm{p}=0.05$.

No soil use significantly altered macroporosity (Mac) in $\mathrm{RL}_{\mathrm{e}}$; however, all sequences influenced microporosity (Mic) in the $0.10-0.20 \mathrm{~m}$ layer and total porosity (TP) in the 0.00-0.10 m layer (Table 3). In $\mathrm{RL}_{\mathrm{a}}$, no soil use significantly altered Mac and Mic; however, all influenced total porosity (TP) in the 0.10$0.20 \mathrm{~m}$ layer (Table 4). In any case, differences in these soil properties were small (a few tenths of a unit) and probably had no effect on crop development.

The Mac values for both soils $\left(\mathrm{RL}_{\mathrm{e}}\right.$ and $\left.\mathrm{RL}_{\mathrm{a}}\right)$ were smaller than those recommended by Tavares Filho et al. (2010). According to them, Mac should exceed $0.10 \mathrm{~m}^{3} \mathrm{~m}^{-3}$ for efficient gas exchange and root development in dryland crops. In this respect, our results are consistent with previous studies, where Mac was also below that limit. Thus, according Baquero et al. (2012), Mac tends to fall below 0.10 $\mathrm{m}^{3} \mathrm{~m}^{-3}$, depending on the number of sugarcane harvests. Also, Centurion et al. (2007) concluded that sugarcane cultivation increased soil density and reduced Mac and TP, in a kaolinitic Red Latosol with a clay content of $334 \mathrm{~g} \mathrm{~kg}^{-1}$ in the 0.00-0.10 m layer, as well as in a kaolinitic-oxidic Red Latosol, containing $488 \mathrm{~g}$ clay kg-1 in the same layer.

None of the soil treatments significantly altered sugarcane productivity at either harvest in either soil (Table 6). Based on the standards of the Brazilian Center for Sugarcane Technology (Centro de 
Table 4. Water stability of soil aggregates (WAS), aggregate mean weight diameter (AMWD), penetration resistance $(\mathrm{PR})$, bulk density $\left(\mathrm{B}_{\mathrm{d}}\right)$, macroporosity $(\mathrm{Mac})$, microporosity (Mic) and total porosity $(\mathrm{TP})$ of the acric Red Latosol after the first sugarcane harvest

\begin{tabular}{|c|c|c|c|c|c|c|c|}
\hline Soil use & WAS & AMWD & PR & $\mathbf{B}_{\mathrm{d}}$ & Mac & Mic & TP \\
\hline & $\%$ & $\mathrm{~mm}$ & $\mathrm{MPa}$ & $\mathrm{Mg} \mathrm{m}^{-3}$ & 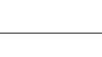 & $\mathrm{m}^{3} \mathrm{~m}^{-3}$ & - \\
\hline & & & & $0.00-0.10 \mathrm{~m}$ & & & \\
\hline $\mathrm{S}$ & 65.80 & $2.98 \mathrm{a}$ & 2.87 & 1.70 & 0.04 & 0.38 & 0.42 \\
\hline SFS & 62.80 & $2.18 \mathrm{~b}$ & 2.74 & 1.70 & 0.03 & 0.37 & 0.40 \\
\hline SMS & 63.20 & $2.55 \mathrm{ab}$ & 3.09 & 1.69 & 0.04 & 0.37 & 0.41 \\
\hline SHS & 64.60 & $2.06 \mathrm{~b}$ & 2.90 & 1.70 & 0.04 & 0.37 & 0.41 \\
\hline $\mathrm{F}$ & $0.40^{\mathrm{ns}}$ & $8.09^{* *}$ & $0.54^{\mathrm{ns}}$ & $0.02^{\mathrm{ns}}$ & $1.05^{\mathrm{ns}}$ & $1.56^{\mathrm{ns}}$ & $3.60^{\mathrm{ns}}$ \\
\hline \multirow[t]{2}{*}{ CV (\%) } & 7.56 & 13.25 & 15.14 & 1.96 & 26.12 & 2.28 & 1.97 \\
\hline & & & & $0.10-0.20 \mathrm{~m}$ & & & \\
\hline $\mathrm{S}$ & $64.20 \mathrm{a}$ & 2.48 & 3.13 & 1.72 & 0.05 & 0.37 & $0.42 \mathrm{a}$ \\
\hline SFS & $55.00 \mathrm{~b}$ & 2.23 & 2.76 & 1.67 & 0.05 & 0.36 & $0.41 \mathrm{ab}$ \\
\hline SMS & $59.20 \mathrm{ab}$ & 2.27 & 2.88 & 1.68 & 0.04 & 0.36 & $0.40 \mathrm{~b}$ \\
\hline SHS & $55.00 \mathrm{~b}$ & 2.42 & 2.74 & 1.72 & 0.04 & 0.36 & $0.40 \mathrm{~b}$ \\
\hline $\mathrm{F}$ & $7.09^{* *}$ & $0.31^{\mathrm{ns}}$ & $1.17^{\mathrm{ns}}$ & $3.23^{\text {ns }}$ & $3.99^{\text {ns }}$ & $3.57^{\mathrm{ns}}$ & $6.12^{* *}$ \\
\hline \multirow[t]{2}{*}{ CV (\%) } & 6.29 & 20.65 & 12.81 & 1.93 & 13.82 & 2.35 & 2.17 \\
\hline & & & & $0.20-0.40 \mathrm{~m}$ & & & \\
\hline $\mathrm{S}$ & 57.60 & & & 1.71 & 0.06 & 0.36 & 0.42 \\
\hline SFS & 51.80 & & & 1.69 & 0.05 & 0.36 & 0.41 \\
\hline SMS & 55.40 & & & 1.72 & 0.05 & 0.36 & 0.41 \\
\hline SHS & 51.00 & & & 1.72 & 0.05 & 0.36 & 0.41 \\
\hline $\mathrm{F}$ & $3.51^{\mathrm{ns}}$ & & & $0.49^{\mathrm{ns}}$ & $1.71^{\mathrm{ns}}$ & $0.38^{\text {ns }}$ & $1.97^{\mathrm{ns}}$ \\
\hline \multirow[t]{2}{*}{ CV (\%) } & 6.85 & & & 2.06 & 20.71 & 3.31 & 2.70 \\
\hline & & & & $0.40-0.60 \mathrm{~m}$ & & & \\
\hline $\mathrm{S}$ & 57.60 & & & 1.67 & 0.05 & 0.38 & 0.43 \\
\hline SFS & 53.20 & & & 1.67 & 0.04 & 0.38 & 0.42 \\
\hline SMS & 54.00 & & & 1.66 & 0.05 & 0.38 & 0.43 \\
\hline SHS & 48.80 & & & 1.65 & 0.05 & 0.37 & 0.42 \\
\hline $\mathrm{F}$ & $2.28^{\mathrm{ns}}$ & & & $0.37^{\mathrm{ns}}$ & $0.57^{\mathrm{ns}}$ & $0.88^{\mathrm{ns}}$ & $0.96^{\text {ns }}$ \\
\hline CV (\%) & 10.01 & & & 2.82 & 28.28 & 2.89 & 2.29 \\
\hline
\end{tabular}

S: soybean, SFS: soybean/fallow/soybean, SMS: soybean/millet/soybean, SHS: soybean/sunn hemp/soybean. ${ }^{\text {ns }}$ not significant, ** significant at the $\mathrm{p}=0.01$ level. Values followed by an identical letter in the same column were not significantly different by Tukey's test at $\mathrm{p}=0.05$.

Tecnologia Canavieira), cited by Benedini \& Bertolani (2008), sugarcane productivity should have been at least $95 \mathrm{Mg} \mathrm{ha}^{-1}$ in $\mathrm{RL}_{\mathrm{e}}$ and $85-90 \mathrm{Mg} \mathrm{ha}^{-1}$ in $\mathrm{RL}_{\mathrm{a}}$ (average of four harvests in each). Therefore, our productivity values exceeded the reference values and, although some soil properties were within the critical ranges, yields were not affected. Assuming that plants are the main sensors of soil quality, the physical properties of soil under sugarcane found in this study were not limiting for crop development and yield. In any case, productivity in the second harvest (2012) was $30-40 \mathrm{Mg} \mathrm{ha}^{-1}$ lower than in the first (2011). Possibly, this reduction was the result of the prevailing climatic conditions (CONAB, 2011; UNICA, 2013).
Roque et al. (2010) also observed no reduction in sugarcane productivity by effect of soil compaction resulting from the management system (traditional mechanical harvesting, mechanical harvesting with traffic control and mechanical harvesting with traffic control and an autopilot). Secco et al. (2004) examined a dystroferric Red Latosol under no-tillage and crop rotation, and found increased compaction to affect some soil properties but not to reduce soybean productivity. This suggests that soil compaction in their study had not reached the critical levels at which crop growth and yield are reduced or that, although compacted, some properties of the system offset the effects of compaction, e.g., continuous pores left by previous crops (Bouma, 1991). 
Table 5. Organic matter (OM), water stability of aggregates (WSA) and bulk density $\left(B_{d}\right)$ of the two soils after the first sugarcane harvest

\begin{tabular}{lccc}
\hline \multicolumn{1}{c}{ Soil } & OM & WSA & B $_{\mathbf{d}}$ \\
\hline & $\mathrm{g} \mathrm{kg}^{-1}$ & $\%$ & $\mathrm{Mg} \mathrm{m}^{-3}$ \\
& & $0.00-0.10 \mathrm{~m}$ \\
Eutroferric Red Latosol & $29.54 \mathrm{a}$ & $74.65 \mathrm{a}$ & $1.46 \mathrm{~b}$ \\
Acric Red Latosol & $21.31 \mathrm{~b}$ & $64.10 \mathrm{~b}$ & $1.70 \mathrm{a}$ \\
F & $95.44^{* *}$ & $71.85^{* *}$ & $210.37^{* *}$ \\
CV (\%) & 7.01 & 6.49 & 1.97 \\
& \multicolumn{3}{c}{$0.10-0.20 \mathrm{~m}$} \\
Eutroferric Red Latosol & $25.61 \mathrm{a}$ & $75.60 \mathrm{a}$ & $1.47 \mathrm{~b}$ \\
Acric Red Latosol & $19.49 \mathrm{~b}$ & $58.35 \mathrm{~b}$ & $1.69 \mathrm{a}$ \\
F & $199.98^{* * *}$ & $83.21^{* *}$ & $307.18^{* *}$ \\
CV (\%) & 7.74 & 5.33 & 2.07 \\
& \multicolumn{3}{c}{$0.20-0.40 \mathrm{~m}$} \\
Eutroferric Red Latosol & $20.56 \mathrm{a}$ & $78.55 \mathrm{a}$ & $1.48 \mathrm{~b}$ \\
Acric Red Latosol & $14.59 \mathrm{~b}$ & $53.95 \mathrm{~b}$ & $1.71 \mathrm{a}$ \\
F & $116.88^{* *}$ & $245.34^{* *}$ & $32976.16^{* *}$ \\
CV (\%) & 9.61 & 5.77 & 2.41 \\
& & $0.40-0.60 \mathrm{~m}$ \\
Eutroferric Red Latosol & $14.38 \mathrm{a}$ & $78.20 \mathrm{a}$ & $1.43 \mathrm{~b}$ \\
Acric Red Latosol & $10.77 \mathrm{~b}$ & $53.40 \mathrm{~b}$ & $1.66 \mathrm{a}$ \\
F & $45.19^{* *}$ & $251.38^{* *}$ & $3482.45^{* * *}$ \\
CV (\%) & 9.95 & 6.35 & 3.08 \\
\hline
\end{tabular}

*** significant at the $\mathrm{p}=0.01$ level. Values followed by an identical letter in the same column were not significantly different by Tukey's test at $\mathrm{p}=0.05$.

Table 6. Sugarcane productivity of the eutroferric Red Latosol $\left(\mathrm{RL}_{\mathrm{e}}\right)$ and of the acric Red Latosol $\left(\mathrm{RL}_{\mathrm{a}}\right)$ in 2011 and 2012

\begin{tabular}{lccrr}
\hline \multirow{2}{*}{ Soil use } & \multicolumn{2}{c}{$\mathbf{R L}_{\mathbf{e}}$} & \multicolumn{2}{c}{$\mathbf{R L}_{\mathbf{a}}$} \\
\cline { 2 - 5 } & 2011 & 2012 & 2011 & 2012 \\
\cline { 2 - 5 } & \multicolumn{4}{c}{$\mathrm{Mg} \mathrm{ha}^{-1}$} \\
S & 149.68 & 97.03 & 140.35 & 98.70 \\
SFS & 157.88 & 131.63 & 145.83 & 129.40 \\
SMS & 147.93 & 108.40 & 134.00 & 111.06 \\
SHS & 148.58 & 98.36 & 150.51 & 114.33 \\
F & $0.57^{\mathrm{ns}}$ & $1.44^{\mathrm{ns}}$ & $0.88^{\mathrm{ns}}$ & $1.34^{\mathrm{ns}}$ \\
CV (\%) & 9.11 & 27.36 & 11.91 & 21.48 \\
\hline
\end{tabular}

S: soybean, SFS: soybean/fallow/soybean, SMS: soybean/millet/ soybean, SHS: soybean/sunn hemp/soybean. ${ }^{\text {ns }}$ not significant.

\section{CONCLUSIONS}

1. None of the crop sequences used during the sugarcane fallow period influenced the chemical properties of the eutroferric Red Latosol or acric Red Latosol.

2. Using a soybean/millet/soybean sequence during the fallow period increased soil aggregation in the acric Red Latosol.
3. None of the crop sequences affected sugarcane productivity in either soil type.

\section{LITERATURE CITED}

AMBROSANO, E.J.; GUIRADO, N.; CANTARELLA, H.; ROSSETTO, R.; MENDES, P.C.D.; ROSSI, F.; AMBROSANO, G.M.B.; ARÉVALO, R.A.; SCHAMMAS, E.A.; ARCARO JÚNIOR, I. \& FOLTRAN, D.E. Plantas para cobertura do solo e adubação verde aplicadas ao plantio direto. Piracicaba, Potafos, 2005. 16p. (Informações Agronômicas, 112)

ANDRADE, R.S.; STONE, L.F. \& SILVEIRA, P.M. Culturas de cobertura e qualidade física de um Latossolo em plantio direto. R. Bras. Eng. Agríc. Amb., 13:411-418, 2009.

ASSIS, R.L.; LAZARINI, G.D.; LANCAS, K.P. \& CARGNELUTTI FILHO, A. Avaliação da resistência do solo à penetração em diferentes solos com a variação do teor de água. Eng. Agríc., 29:558-568, 2009.

AZEVEDO, M.C.B. Efeito de três sistemas de manejo físico do solo no enraizamento e na produção de cana-de-açúcar. Londrina, Universidade Estadual de Londrina, 2008. 102p. (Tese de Doutorado)

BAQUERO, J.E.; RALISCH, R.; MEDINA, C.C.; TAVARES FILHO, J. \& GUIMARÃES, M.F. Soil physical properties and sugarcane root growth in a Red Oxisol. R. Bras. Ci. Solo, 36:63-70, 2012.

BENEDINI, M.S. \& BERTOLANI, F.C. Carta de solos e ambientes de produção. R. Coplana, 6:24-25, 2008.

BOUMA, J. Influence of soil macroporosity on environmental quality. Adv. Soil Sci., 46:1-37, 1991.

CARVALHO, L.A.; M. NETO, V.J.; SILVA, L.F.; PEREIRA, J.G.; NUNES, W.A.G.A. \& CHAVES, C.H.C. Resistência mecânica do solo à penetração (RMP) sob cultivo de canade-açúcar, no município de Rio Brilhante-MS. Agrarian, 1:7-22, 2008 .

CENTURION, J.F.; FREDDI, O.S.; ARATANI, R.G.; METZNER, A.F.M.; BEUTLER, A.N. \& ANDRIOLI, I. Influência do cultivo da cana-de-açúcar e da mineralogia da fração argila nas propriedades físicas de Latossolos Vermelhos. R. Bras. Ci. Solo, 31:199-209, 2007.

COMPANHIA NACIONAL DE ABASTECIMENTO - CONAB. Acompanhamento de safra brasileira: Cana-de-açúcar, terceiro levantamento, dezembro/2011. Brasília, 2011. 20p.

COMPANHIA NACIONAL DE ABASTECIMENTO - CONAB. Acompanhamento de safra brasileira: Cana-de-açúcar, terceiro levantamento, dezembro/2012. Brasília, 2012. 18p.

DEXTER, A.R. Mechanics of root growth. Plant Soil, 98:303-312, 1987.

EMPRESA BRASILEIRA DE PESQUISA AGROPECUÁRIA EMBRAPA. Manual de métodos de análise de solo. 2.ed. Rio de Janeiro, Centro Nacional de Pesquisa de Solos, 1997. 212p. (Documentos, 1) 
FERNANDES, C.; CORA, J.E. \& MARCELO, A.V. Soil uses in the sugarcane fallow period to improve chemical and physical properties of two Latosols (Oxisols). R. Bras. Ci. Solo, 36:283$294,2012$.

GROSSMAN, R.B. \& REINSCH, T.G. Bulk density and linear extensibility. In: DANE, J.H. \& TOPP, G.C., eds. Methods of soil analysis. Madison, Soil Science Society of America, 2002. Part 4. p.201-228. (SSSA Book Series, 5)

LOWERY, B. \& MORRISON, J.E. Soil penetrometers and penetrability. In: DANE, J.H. \& TOPP, G.C., eds. Methods of soil analysis. Madison, Soil Science Society of America, 2002. Part 4. p.363-388. (SSSA Book Series, 5)

LUCA, E.F.; FELLER, C.; CERRI, C.C.; BARTHÈS, B.; CHAPLOT, V.; CAMPOS, D.C. \& MANECHINI, C. Avaliação de atributos físicos e estoques de carbono e nitrogênio em solos com queima e sem queima de canavial. R. Bras. Ci. Solo, 32:789-800, 2008.

MARCELO, A.V.; CORÁ, J.E.; FERNANDES, C.; MARTINS, M.R. \& JORGE, R.F. Crop sequences in no-tillage system: Effects on soil fertility and soybean, maize and rice yield. R. Bras. Ci. Solo, 33:417-428, 2009.

MARTENS, D.A. Plant residue biochemistry regulates soil carbon cycling and carbon sequestration. Soil Biol. Biochem., 32:361369,2000 .

MARTINS, M.R.; ANGERS, D.A. \& CORÁ, J.E. Carbohydrate composition and water-stable aggregation of an Oxisol as affected by crop sequence under no-till. Soil Sci. Soc. Am. J., 76:475-484, 2012b.

MARTINS, M.R.; ANGERS, D.A. \& CORÁ, J.E. Co-accumulation of microbial residues and particulate organic matter in the surface layer of a no-till Oxisol under different crops. Soil Biol. Biochem., 50:208-213, 2012a.

MARTINS, M.R.; ANGERS, D.A. \& CORÁ, J.E. Non-labile plant $\mathrm{C}$ contributes to long-lasting macroaggregation of an Oxisol. Soil Biol. Biochem., 58:153-158, 2013.

MASCARENHAS, H.A.A.; TANAKA, R.T.; COSTA, A.A.; ROSA, F.V. \& COSTA, V.F. Efeito residual de leguminosas sobre rendimento físico e econômico da cana-planta. Campinas, Instituto Agronômico, 1994. 15p. (Boletim Científico IAC, 32)

BRASIL. Ministério da Agricultura Pecuária e Abastecimento. Culturas: Cana-de-açúcar. Available at: <http:// www.agricultura.gov.br/vegetal/culturas/cana-de-acucar $>$. Accessed: Dec. 12, 2012.

NIMMO, J.R. \& PERKINS, K.S. Aggregate stability and size distribution. In: DANE, J.H. \& TOPP, G.C., eds. Methods of soil analysis. Madison, Soil Science Society of America, 2002. Part 4. p.317-328. (SSSA Book Series, 5)

PORTUGAL, A.F.; COSTA, O.D.V. \& COSTA, L.M. Propriedades físicas e químicas do solo em áreas com sistemas produtivos e mata na região da Zona da Mata mineira. R. Bras. Ci. Solo, 34:575-585, 2010.
RAIJ, B.van; ANDRADE, J.C.; CANTARELLA, H. \& QUAGGIO, J.A. Análise química para avaliação da fertilidade de solos tropicais. Campinas, Instituto Agronômico de Campinas, 2001. 285p.

REICHARDT, K. Capacidade de campo. R. Bras. Ci. Solo, 12:211-216, 1988.

ROQUE, A.A.O.; SOUZA, Z.M.; BARBOSA, R.S. \& SOUZA, G.S. Controle de tráfego agrícola e atributos físicos do solo em área cultivada com cana-de-açúcar. Pesq. Agropec. Bras., 45:744-750, 2010.

SECCO, D.; REINERT, D.J.; REICHERT, J.M. \& ROS, C.O. Produtividade de soja e propriedades físicas de um Latossolo submetido a sistemas de manejo e compactação. R. Bras. Ci. Solo, 28:797-804, 2004.

SERAFIM, M.E.; VITORINO, A.C.T.; PEIXOTO, P.P.P.; SOUZA, C.M.A. \& CARVALHO, D.F. Intervalo hídrico ótimo em um Latossolo Vermelho distroférrico sob diferentes sistemas de produção. Eng. Agric., 28:654-665, 2008.

SILVA, I.F. \& MIELNICZUK, J. Ação do sistema radicular de planta na formação e estabilização de agregados do solo. R. Bras. Ci. Solo, 21:113-117, 1997.

SOUZA, Z.M.; MARQUES JUNIOR, J.; PEREIRA, G.T. \& SAENZ, C.M.S. Spatial variability of aggregate stability in Latosols under sugarcane. R. Bras. Ci. Solo, 33:245253, 2009.

SPIRONELLO, A.; RAIJ, B.van; PENATTI, C.P.; CANTARELLA, H.; MORELLI, J.L.; ORLANDO FILHO, J.; LANDELL, M.G.A. \& ROSSETTO, R. Cana-de-açúcar. In: RAIJ, B.van.; CANTARELLA, H.; QUAGGIO, J.A. \& FURLANI, A.M.C., eds. Recomendações de adubação e calagem para o Estado de São Paulo. 2.ed. Campinas, Instituto Agronômico/Fundação IAC, 1997. p.237-239. (Boletim Técnico, 100)

TAVARES FILHO, J.; BARBOSA, G.M.C. \& RIBON, A.A. Physical properties of dystrophic Red Latosol (Oxisol) under different agricultural uses. R. Bras. Ci. Solo, 34:925933, 2010.

TAYLOR, H.M.; ROBERSON, G.M. \& PARKER Jr., J.J. Soil strength-root penetration relations to medium to coarse textured soil materials. Soil Sci., 102:18-22, 1966.

TORMENA, C.A.; SILVA, A.P. \& LIBARDI, P.L. Caracterização do intervalo hídrico ótimo de um Latossolo Roxo sob plantio direto. R. Bras. Ci. Solo, 22:573-581, 1998.

UNIÃO DA INDÚSTRIA DE CANA-DE-AÇÚCAR - UNICA. Acompanhamento de safra: Relatório final da safra 2011/ 2012 na região centro-sul. Available at: <http:// www.unicadata.com.br/listagem.php?idMn=72>. Accessed: March 18, 2013.

WOHLENBERG, E.V.; REICHERT, J.M.; REINERT, D.J. \& BLUME, E. Dinâmica da agregação de um solo francoarenoso em cinco sistemas de culturas em rotação e em sucessão. R. Bras. Ci. Solo, 28:891-900, 2004. 